\title{
Strengthening Student Skills through Training in Making Meatballs with Culled Chicken Meat
}

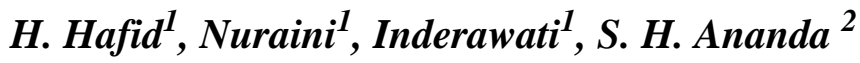 \\ ${ }^{1}$ Animal Science Departement, Faculty of Animal Science, Halu Oleo University, Kendari, Indonesia \\ ${ }^{2}$ Nutrition Study Program, STIKES Karya Kesehatan, Kampus Anduonohu, Kendari, Indonesia
}

\begin{abstract}
Students as agents of change are required to have a lot of knowledge and skills during their studies. The addition of the ability of the skills of the students should be obtained based on practical activities during the lecture, but is often constrained by the unpreparedness of lab facilities and adequate infrastructure. This has an impact on student mastery of skills is not optimal. Application of science and technology activities aimed to establish a student majoring in animal husbandry skills through training making meatballs with chicken base material salvage. Methods are activities undertaken by: (1) lectures and discussions on potential, prospects and agribusiness agroindustry meatballs, (2) demonstration and coaching of making meatballs, (3) motivated the development of entrepreneurial spirit. The results showed that activities of the training material presented and received positive response from participants was satisfactory considering there has not yet been carried out similar activities. Generally, the participants wanted to adopt the material about making meatballs with chicken base material reject rate. Concluded that the target audience consists of students majoring in animal husbandry are very enthusiastic and active in the manufacture of technical guidance meatballs. In general, trainees wishing to do entrepreneurship by producing meatballs made from chicken meat laying reject rate.
\end{abstract}

Keywords: Artificial meat, Soybeans, Counseling, Training

\begin{abstract}
Abstrak. Mahasiswa sebagai agen perubahan diharuskan memiliki banyak pengetahuan dan keterampilan selama masa studi mereka. Penambahan kemampuan keterampilan mahasiswa harus diperoleh berdasarkan kegiatan praktis selama kuliah, tetapi sering dibatasi oleh ketidaksiapan fasilitas laboratorium dan infrastruktur yang memadai. Hal ini berdampak pada penguasaan keterampilan siswa yang tidak optimal. Penerapan ilmu pengetahuan dan teknologi ini bertujuan meningkatkan keterampilan mahasiswa jurusan peternakan melalui pelatihan pembuatan bakso dengan menggunakan bahan dasar daging ayam afkir. Metode kegiatan yang dilakukan oleh:
\end{abstract}

*Corresponding author at: Jl. HEA Mokodompit Kampus Bumi Tridarma Anduonohu

E-mail address: harapin.hafid@uho.ac.id 
(1) ceramah dan diskusi tentang potensi, prospek dan agribisnis bakso, (2) demonstrasi dan pelatihan pembuatan bakso, (3) memotivasi pengembangan semangat kewirausahaan. Hasil kegiatan menunjukkan materi pelatihan dipresentasikan mendapat respons positif dari peserta. Para perserta cukup puas mengingat belum ada kegiatan serupa yang dilakukan. Secara umum, para peserta ingin mengadopsi materi tentang cara membuat bakso dengan bahan dasar ayam petelur afkir. Disimpulkan bahwa khalayak sasaran terdiri dari mahasiswa jurusan peternakan sangat antusias untuk memahami dan menerapkan materi yang diajarkan, dan aktif dalam praktek pembuatan bakso. Semua peserta pelatihan yang ingin melakukan kewirausahaan dengan membuat bakso dari daging ayam petelur afkir.

Kata Kunci: Keterampilan, Mahasiswa, Pelatihan, Bakso, Ayam afkir Received 20 October 2018 | Revised 10 February 2019 | Accepted 5 April 2019

\section{Introduction}

Higher Education is a scientific institution that is responsible for improving the quality of human resources in Indonesia. Through the learning process in the form of lecture and practicum activities, efforts are made to carry out the process of transferring knowledge in the form of materials of Science, Technology and Art as a basis for the concept and development in filling the nation's development.

At Haluoleo University, as one of the leading State Universities in Eastern Indonesia is one example of the development of science and technology through tridarma activities in the form of education and teaching, research and community service. Nevertheless, one of the classic obstacles that is often encountered is the limited facilities and infrastructure to make it happen. As well as in the implementation of education and teaching, especially practicum activities are often constrained by inadequate facilities and infrastructure so that the level of mastery of students (students) is not optimal.

The Department of Animal Husbandry at the Faculty of Agriculture is one example of the limited facilities and infrastructure of student practicum, especially in the Basic Animal Husbandry Technology course, which aims to introduce basic concepts of livestock products, the principles of handling and processing and preservation. The limitations felt so far are practicum material, equipment and insufficient time available to strengthen student mastery of practicum material.

Through this community service activity, it is attempted to synchronize community service with education and teaching, in the form of efforts to strengthen students' skills through meat processing [1].[2].[3], using meat-based ingredients Afkir chicken which is 
a cheap economic waste product from laying chicken farms. Meatballs are food made from meat as the main ingredient, both beef, chicken, fish, shrimp and duck meat. Meatballs are mashed meat and mixed with other additives and spices so the meatballs are more delicious. Generally meatballs are formed into spheres resembling small balls. The taste of delicious meatballs and chewy texture makes meatballs favored by children to adults [5][6][7][8]. Meatballs are generally processed into various dishes, such as soup meatballs, grilled meatballs, sauteed meatballs and various other meatball dishes. Meatballs found in markets and supermarkets are made from various types of meat, including beef, chicken and fish.

With this activity, it is expected to provide students with skills to make meatballs, use of reject chicken as raw material for meatballs and stimulate students entrepreneurial spirit through processing low-value raw materials to produce more reliable power.

\section{Method}

\section{Target Audiences}

Members of the community groups that are the target of this service activity are: $\mathrm{V}$ semester students (five) who are programming Basic Animal Husbandry Technology courses and other students in Animal Husbandry who intend to increase their knowledge and skills. It is hoped that the participants of this activity will be able to adopt technology that is guided, demonstrated and practiced and spread it to the wider community.

\section{Implementation Procedure}

Technical guidance in the form of strengthening the skills of students majoring in animal husbandry through training in making meatballs with basic ingredients of rejected chicken meat. is an innovation carried out by the lecturer team of the Animal Husbandry Department of the in Halu Oleo University to increase the students' knowledge and skills in mastering livestock yield technology, especially in producing meatball processed products, and new uses in limited circles in universities, through this activity, were introduced to students can solve identified problems.

The event organizer, namely the lecturer in Animal Husbandry Halu Oleo University, assisted by students as a companion in the field, acted as an agent of transfer of knowledge. While the people who are the target, provide cooperation so that the transfer of knowledge in question, can take place well.

\section{Service Method}

The students selected to be the target audience in this training activity will carry out activities that include: 
1. Following counseling about the introduction and processing of meatballs,

2. Directly involved in the demonstration of making meatballs,

3. Practice directly the process of making meatballs with rejected chicken meat as basic ingredients,

4. Practicing in daily life in the form of a commercial production plan in the form of entrepreneurial activities of animal husbandry student groups.

The method of implementing this activity is carried out in two forms, namely:

1. Non-physical activities which include counseling about the process of making meatballs with raw materials for rejected laying chicken meat.

2. Physical activity, in the form of a demonstration of making reject chicken meatballs with the following stages:

- The Activity Proposal Team socialized the activity plan for the students,

- The Team of Proponents of the activity together with the Chairperson of the

Study Program / Department assigns 30 prospective students to attend training in Community Service activity,

- The Team of Proponents of the activity with selected participants determine the schedule of training activity plans,

- The training by the Proposal Team will be carried out regularly according to

a predetermined schedule with the knowledge of the Study Program Chairperson or the Head of the Department.

5. Before training is carried out or the practice of making culled chicken meatballs, begins with counseling on how to make the making of meatballs with rejected chicken race meat as the basic ingredient, which can be seen in Table 1.

Table 1. Composition of chicken meatball material [8]

\begin{tabular}{clcc}
\hline No & Ingredient & Weight $(\mathbf{g})$ & Percentage \\
\hline 1 & Chicken meat & 250 & 78 \\
2 & Tapioka flour & 50 & 16 \\
3 & Ice cube & 10 & 3 \\
4 & Salt & 3 & 1 \\
5 & Papper & 3 & 1 \\
5 & Garlic & 3 & 1 \\
\hline Total & & 319 & 100 \\
\hline
\end{tabular}

The stages of activities carried out in the manufacture of meatballs with basic ingredients of reject chicken meat are as follows:

a. Preparation of materials, where the tool is in the form of: meat used in making these meatballs is obtained from laying chicken farms in Kendari City. The sex of the hen and the age of the chickens with approximately 24 months, is estimated because it is 
not productive to produce eggs. The ingredients of meat used are breast and thigh meat. All meat samples are fresh (prerigor phase). The flour material used in making meatballs is a combination of tapioca flour, starch, cornstarch and sago flour, with the amount of each used $10-15 \%$ of the weight of the meat. To give flavor to the taste of meatballs in general, flavorings are added.

b. Preparation of materials, where the tool is in the form of: meat used in making these meatballs is obtained from laying chicken farms in Kendari City. The sex of the hen and the age of the chickens with approximately 24 months, is estimated because it is not productive to produce eggs. The ingredients of meat used are breast and thigh meat. All meat samples are fresh (prerigor phase). The flour material used in making meatballs is a combination of tapioca flour, starch, cornstarch and sago flour, with the amount of each used $10-15 \%$ of the weight of the meat. To give flavor to the taste of meatballs in general, flavorings are added.

c. The process of making meatballs, carried out as follows: meat sample meat that is ready to be cleaned from fat and sliced into small pieces and then ground until smooth. Milling is done by adding $20 \%$ ice cubes. After smoothing, then the results of the grinding were added to $2.5 \%$ salt and seasoning consisting of $2 \%$ garlic and monosodium glutamate to taste. After being homogeneous, then added flour ingredients of $10 \%$ each treatment. The ingredients that have been added earlier are mixed to get a homogeneous mixture. The printed dough is round with a diameter of $\mathrm{cm} 3 \mathrm{~cm}$, then put in cold water for 10 minutes, after that it is boiled in water with a temperature of $70-80^{\circ} \mathrm{C}$ for 15 minutes after the meatballs are cooked (looks floating). Further testing of the parameters observed.

d. Panelists tested using a like or dislike response to the nature of the meatball products that had been made. The hedonic scale ranges from values 1 to 5 for organoleptic tests which include taste, aroma, color, texture, elasticity and general acceptance of panelists [9][10]. In detail the implementation of making meatballs can be seen in Figure 1 below. 


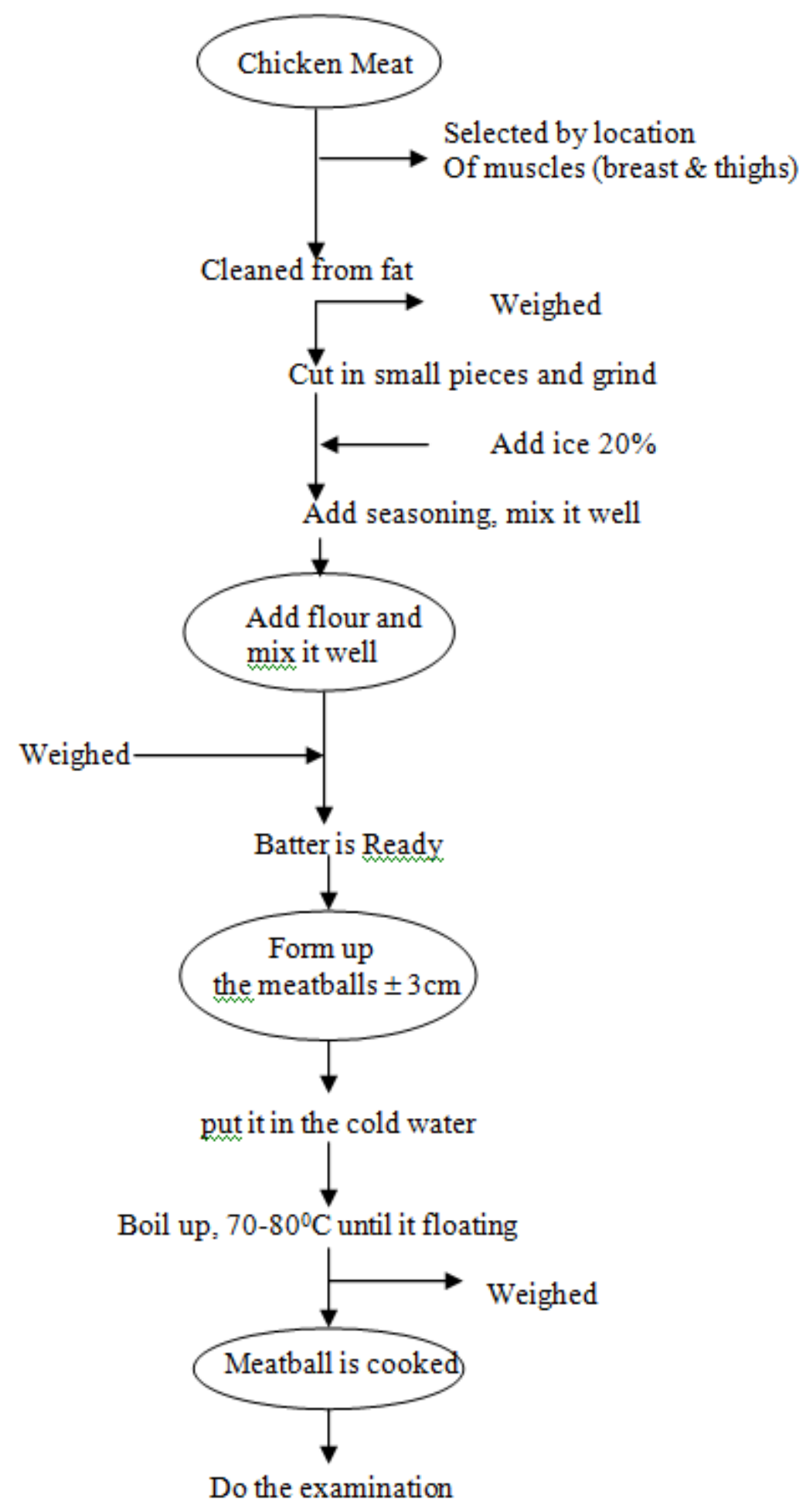

Figure 1. Flowchart of making meatballs [6] [11] [12]

\section{Result and Discussion}

The implementation of community service activities will be monitored and evaluated by the LPPM to determine the indicators or the level of success of the activities and jointly find a solution if obstacles are found. Evaluation of activities will be carried out by a team of community service institutions in Halu Oleo University together with the activity implementation team. 
Evaluation of non-physical activities is to see the level of understanding, participation in each activity, discussion and follow-up plan of the participants. At the end of the activity a questionnaire will be distributed to each participant. Solutions will also be sought for possible constraints faced by participants in applying the results of training activities.

Evaluate physical activities by looking directly at the package of activities carried out based on the achievement of targets according to the specified schedule, the number of active participants, the level of understanding of participants and acceptance of the resulting meatball products.

The results of the evaluation are reported periodically through the progress report of the activity, the level of achievement of targets and the final report of activities and the possibility of publication. The final report will be completed with photos of the activities. Monitoring activities will still be carried out even though this project has been completed and will be made into an entrepreneurial-assisted student group by the Haluoleo University Community Service Institute.

The training activities in the form of technical guidance through training in making meatballs with basic ingredients of culled chicken to optimize the ability to master appropriate technology, especially meat processing technology to Animal Husbandry students, so that in the future it can encourage the formation of entrepreneurial spirit and creative employment for students and alumni. The training / technical guidance activities have been carried out in the Department of Animal Husbandry by a Team from the Department of Animal Husbandry, Faculty of Animal Husbandry, Halu Oleo University. Material presented in the form of: percentage of the business prospects of processed food from meat, especially meatballs, introduction of ingredients and equipment needed in meatball processing, knowledge of meat and its quality, seasoning and composition of ingredients and techniques for making meatballs have received positive and satisfying response the training participants remember that so far it is very rare to do similar activities. Even though students as intellectual candidates really need appropriate skills that can be used as a means of starting an entrepreneurial business. In general students are very enthusiastic in the practice of making meatballs and are very interested in applying it in their lives.

Questions and answers or between the Implementation Team and the target audience who are generally students, took place after counseling and demonstrations were held. The lecture material which focuses on optimizing the empowerment of entrepreneurial 
potential for Unhalu Animal Husbandry students, especially in developing entrepreneurship, the prospects for development and market opportunities in general are very interesting and enthusiastic participants. Besides that they are also very interested in attending lectures and demonstrations about the process of making culled chicken meatballs which are generally the most common obstacle factors they face in the manufacturing process.

Extension activities and demonstrations of making meatballs made from reject chicken got very serious attention from the participants, which was marked by the presence of $100 \%$ of the participants. Generally they want to prove themselves the training material that has been delivered to them. The participants were very active asking in making meatballs because they really like meatballs that taste good and savory that they have tasted.

The initial stage of the demonstration material was to teach the participants about the relatively inexpensive use of culled chicken meat to be the basic ingredient in making meatballs, the introduction of ingredients and spices, the grinding process and mixing of spices and the formation of dough and meatball balls. and technical matters that support the success of meatball production such as the use of ice cubes, cooking water temperature, and so on.

The results of this activity are expected to increase the interest of Animal Husbandry majors to seek entrepreneurship in making meatballs using basic ingredients of rejected laying chicken meat and can be emulated by other communities around them. By providing better knowledge and skills about how to make meatballs, it will ultimately have an impact on increasing the income of the people who cultivate it, especially in Kendari City. Participants' response to the training activities, among others, was realized with a number of questions about various matters relating to the material and the prospects of the meatball manufacturing business being trained.

When observed there are several things that become supporting factors and the inhibiting factors in this training activity are:The post-intervention activities were the end of a series of counseling and training activities by giving a post-test to the participants using a questionnaire about their knowledge of artificial meat. The post-test results showed an increase in the community knowledge in which $81 \%$ of participants had a good knowledge of artificial meat. 


\section{Supporting Factors}

Some of the things that are the supporting and driving factors in the implementation of community service activities are as follows :

1. The response of the guidance participants who are students of the Animal Husbandry Department to the material from the technical guidance activities delivered by the Animal Husbandry Department Team was very enthusiastic and kind.

2. The marketing aspect of livestock products in the form of meatball products by local people is very popular and guaranteed with the support of nearby markets and smooth transportation facilities and infrastructure and high interest in culinary meatballs.

3. In general, people in Kendari city are very fond of eating meatballs without being limited by age differences. This greatly supports the development of meatball manufacturing businesses for student entrepreneur groups.

\section{Obstacle Factor}

In the implementation of community service activities there are still several inhibiting factors which are generally :

1. Community knowledge and skills are still low, including students about how to choose materials and process good production (good manufacturing practices).

2. The Lack and limited business capital is an obstacle to the development of student interest in entrepreneurship in making rejected chicken meatballs.

\section{Conclusion}

The training participants consisting of Animal Husbandry students were very interested and enthusiastic about receiving training materials and were very active in participating in the training activities to strengthen the skills of animal husbandry students through training in making meatballs with raw materials for chicken meat as an effort to optimize the empowerment of community / student potential. This situation shows that students majoring in animal husbandry are still in desperate need of additional practical material because of the limited opportunities they have. 


\section{References}

[1] Buckle K. A. R. A. Edward Feet and M. Wooton. 1985. Food Science. University of Indonesia, Jakarta.

[2] Hafid H. and A Syam. 2007. Effect of aging and muscle location on organoleptic quality of beef. Buletin Peternakan. 31(4) : 209-216.

[3] Soeparno, 2005. Meat Science and Technology. Gadjah Mada University Press, Yogyakarta.

[4] Elviera, G., 1988. Effect of withering beef on the quality of meatballs. Thesis, Faculty of Agricultural Technology, IPB, Bogor.

[5] D. Muchtadi. and R. Dede. 1996. Making meatballs and sausages from the basic ingredients of cone meat cooked by extraction and evaluating its quality. Food and Nutrition Technology. Faculty of Agricultural Technology, IPB, Bogor.

[6] Hafid. H. 2005. Consumer acceptance of beef meatballs from different ingredients of meat and flour. Buletin Penelitian Sosek. 15 (8) : 89-95.

[7] Hafid, H. 2017. Introduction to Meat Processing: Theory and Practice. First printing. Alfabeta Publisher. Bandung.

[8] Nasution, F. A., H. Hafid, and R. Aka. 2015. The effect at sweet potato flour, kabuto, and sagu on broiler chicken meet ball quality. Proceeding International Seminar Inproving Tropical Animal Production. Faculty of Animal Science Halu Oleo University. Kendari . Page . 253.

[9] Nuraini, I. Armila, H. Hafid, and S. H. Ananda. 2019. Quality of chicken meat which is given treatment of electric stimulation. Journal of Physics: Conference Series. 1364, 012072. Page 1-7.

[10] Hafid H, A. Napirah, S. M. Sarifu, Rahman, Inderawati, Nuraini, and Hasnudi. 2018. Effect of electrical stimulation on physical and organoleptic properties of muscovy duck meat. JITV. 23 (4): 202-209.

[11] Rosita, F. H. Hafid, and R. Aka. 2015. Cooking losses and organoleptic qualities of beef meatballs with the addition of sago flour to different levels. JITRO 2 (1): 14-20.

[12] Nullah, L. N. H. Hafid, and A. Indi. 2016. The effect of local filler material on the physical and chemical quality of laying hens meatballs. JITRO 3 (2): 58-63. 